\title{
Tarragon (Artemisia Dracunculus L.) Could Alleviate Negative Effects of Stocking Density in Laying Hens
}

\section{EAuthor(s)}

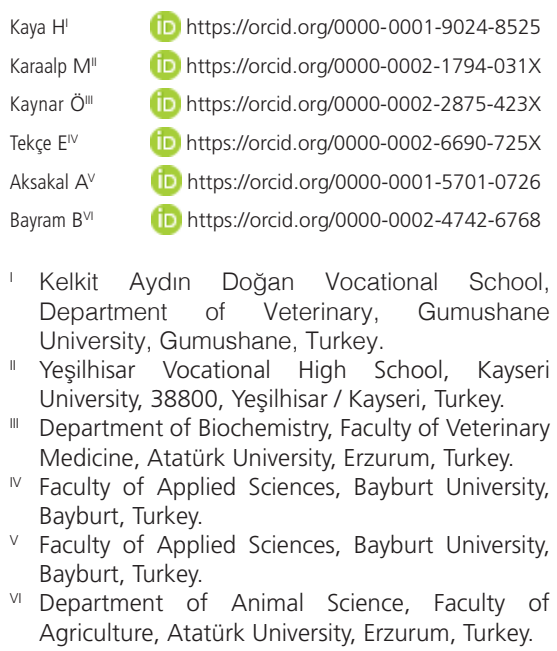

\section{Mail Address}

Corresponding author e-mail address Hacer Kaya

Kelkit Aydın Doğan Vocational School, Department of Veterinary, Gumushane

University, Gumushane, Turkey.

Phone: +9045623310 32

Email: hacerkaya@gumushane.edu.tr

\section{aKeywords}

Antioxidant; bacteria; IgG; stocking density; tarragon.

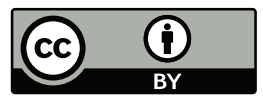

Submitted: 30/April/2020

Approved: 12/November/2020

\section{ABSTRACT}

The study was conducted to determine the effects of stocking density (SD, 5 or 7 layers/cage) and tarragon (Artemisia dracunculus L.) diet supplementation at four levels $(0,1.2,6$ and $12 \mathrm{~g} / \mathrm{kg}$ feed) on performance, certain egg characteristics, serum, liver, egg yolk and small intestine bacteria parameters in laying hens. The experiment was carried out over a period of 8 weeks, with 192 Lohman Brown commercial hybrids at 50-w-age. The results showed that an increased SD reduced feed intake ( $\mathrm{Fl} ; p<0.01)$ and egg production $(p<0.05)$, but had no effect on the weight gain, feed conversion ratio, damaged egg ratio, egg weight and egg quality ( $p>0.05)$ parameters. The supplementation of tarragon to the diet reduced the FI and damaged egg ratio $(p<0.01)$, and improved egg production and FCR $(p<0.01)$. While an increased SD reduced serum total antioxidants $(p<0.05)$, it elevated corticosterone (CORT) and total oxidant serum (TOS) $(p<0.05)$. Tarragon was found to enhance total immunoglobulin $(p<0.05)$, but to decreased the CORT and TOS of the serum $(p<0.05)$. An increased SD raised the malondialdehyde (MDA) in the serum $(p<0.001)$, liver $(p<0.05)$ and yolk $(p<0.001)$. Tarragon supplementation reduced MDA of the serum $(p<0.05)$, liver $(p<0.001)$ and yolk $(p<0.001)$. E. coli and total Mesophilic Aerobic Bacteria counts in the small intestine were raised $(p<0.001)$ with increased SD. Tarragon decreased $(p<0.05)$ mesophilic aerobic bacteria. It was thus found that, tarragon supplementation can be considered generally effective in improving performance parameters, alleviating stress-induced negativities, reducing lipid peroxidation, regulating the immune system and controlling some intestinal microorganisms.

\section{INTRODUCTION}

A high $(\mathrm{H})$ stocking density (SD) is one approach to increasing profitability in conventional poultry production, although HSD decreases animal welfare and increases stress. In the event of stress, the adrenocorticotropic hormone secreted from the anterior pituitary affects the adrenal cortex for the synthesis of glucocorticoids (corticosterone [CORT] and cortisol). The primary glucocorticoid released from the hypothalamic-hypophysis-adrenal (HPA) axis with the effects of stress factors is corticosterone in poultry (Ralph \& Tilbrook, 2016). An increase in the CORT hormone in poultry has been found to decrease performance (Kutlu \& Forbes, 1993; Mirfendereski \& Jahanian, 2015; Sahin et al., 2002; and immunity parameters (Mirfendereski \& Jahanian, 2015; von Eugen et al., 2019). Stress factors effect total serum antioxidant (TAS) and oxidant (TOS) concentrations (Sohail et al., 2011). While light and moderate stressors can be easily handled, severe stressors can cause pathological conditions (Moberg \& Mench, 2000). That said, contradictory data has been presented with regards to the reaction of the HPA axis in connection with the period and intensity of the stressors in chickens (Ericsson, 2016). 
Basic free radicals deriving from oxygen in living systems play a role in oxidative stress and oxidative rancidity (Conforti et al., 2006). Oxidative stress damages important biological molecules, and when the body's ability to rid itself of radicals is reduced, at least one of the pathological findings in animals (Fellenberg \& Speisky, 2006) lipid peroxydation in animal products (Galobart et al., 2001) occur. Today, medicinal aromatic plants with high phenolic and flavonoid content, as well as their extracts, are used to alleviate the negative effects of stress factors and synthetic antioxidants. It has been stated that the dietary supplementation of antioxidant substances regulates corticosteroid synthesis in the adrenal glands (Mirfendereski \& Jahanian, 2015; Von Eugen et al., 2019) enhances immunity (Mirfendereski \& Jahanian, 2015) and decreases the lipid peroxidation of egg yolk (Botsoglou et al., 2005; Karaalp et al., 2018). In addition, dietary supplementations of anti-microbial substances suppress pathogenic microflora in the digestive system (Wenk, 2000).

Artemisia dracunculus L., which is one of the 22 types of the Artemisia species grown in Turkey, has both antioxidant and antibacterial features. The dominant ingredients in the oil of Artemisia dracunculus L. plant, which is a multi-year woody plant, are (Z)-anethole $(81 \%)$, (Z)- $\beta$-ocimene (6.5\%), (E)- $\beta$-ocimene $(3.1 \%)$, limonene (3.1\%) and methyleugenol (1.8\%) (Kordali et al. 2005). In another study conducted in the same period and in the same region, the $\beta$-ocimene (1.237.21 arbitrary units, $A \cup \times 10-6), \alpha$-pinene (114.4 $\left.A \cup \times 10^{-6}\right), \beta$-thujene (166.92 AU×10-6), D-limonene

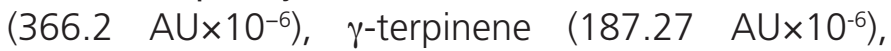
Terpinolene (129.92 AU $\times 10^{-6}$ ) and Estragole (11 242 $\mathrm{AU} \times 1^{-6}$ ) levels were stated (Yilmaz et al. 2019). There have to date been several studies examining the effects of Artemisia annua (Brisibe et al., 2008) Artemisia sieberi (Khalaji et al., 2011; Kheirabadi et al., 2014) and Artemisia dracunculus (Gharetappe et al., 2015; Hosseinzadeh \& Moghaddam, 2014), all of which are Artemisia spp, in broiler chickens; and while there have been a few studies examining effects of Artemisia annua in laying hens (Brisibe et al., 2008; Li et al., 2016), no study has been found with specific focus on Artemisia dracunculus.

The initial humoral and cellular immune response takes the form of cytokines released from activated $T$ cells. These cytokines are transformed into plasma cells that are capable of producing antibodies (IgG, IgA and $\operatorname{lgM}$ ) through the stimulation of $B$ lymphocytes (Taheri et al., 2005). There are three main antibody classes containing $\lg \mathrm{M}, \lg \mathrm{A}$ and $\lg \mathrm{G}(\lg \mathrm{Y})$ that have been identified in chickens (Ayaz et al., 2008). IgG in chickens accounts for approximately $75 \%$ of the total serum antibodies (Carlander et al., 2000).

One of the more common bacteria found in animal intestines is Escherichia coli (E. coli) (Omidpanah et al., 2016). Some serotypes of $E$. coli are pathogens for poultry (Dho-Moulin \& Fairbrother, 1999; and some serotypes are pathogens for humans (Kassaify and Mine 2004). Aerobic mesophilic bacteria and their metabolites are the main pathogenic microorganisms causing environmental pollution (Witkowska \& Sowińska, 2013).

The present study evaluates the effects of the dietary supplementation of Artemisia dracunculus $L$. in commercial laying hens housed in different SD on performance, certain egg quality characteristics, peroxidation, immune response and some intestinal bacteria.

\section{MATERIALS AND METHODS}

\section{Animals, Experimental Desing and Feed}

All procedures were approved by the Animal Experiments Local Ethics Committee of Gumushane University (Approval date: 10.05.2017; Decision No: 01-07). A total of 192 Lohman Brown layer hens (at $50-$ w old) were used in a $2 \times 4$ factorial (with 4 replications) arrangement of treatments that included two cage densities [5, normal (N) SD and 7 (HSD) hens per cage; $90 \times 45 \times 35 \mathrm{~cm}$, and four ratios of ground tarragon $(0,1.2,6$ and $12 \mathrm{~g} / \mathrm{kg}$ diet, T0, T1.2, T6 and T12, respectively). The SDs were 810 and $580 \mathrm{~cm}^{2}$ area per hen in the NSD and HSD groups, respectively. The ingredients and chemical compositions of the commercial feed are presented in Table 1. The tarragon was obtained from the village of Yedigözeler in the Bayburt Province, and was kept stored in a cool and dry environment. The total antioxidant amount of tarragon was measured as $0.833 \mathrm{mmol} / \mathrm{g}$ according to Erel (2004). The dietary supplementation of $0,1.2,6$ and $12 \mathrm{~g} / \mathrm{kg}$ of ground tarragon corresponded to 0,1 , 5 and $10 \mathrm{mmol}$ of additional antioxidant, respectively. The first 2-w (48 to 50-w old) was the adaptation period. The main trial lasted for a total of $8-w$, from 50 to $58-w$ old. The hens were exposed to $16 \mathrm{~h}$ light and $8 \mathrm{~h}$ darkness, feed and water were provided ad libitum, and the accommodation temperature was maintained at 21 to $24^{\circ} \mathrm{C}$ throughout the trial period. The diet was analyzed according to standard AOAC (2007), procedures for chemical composition. 
Kaya H, Karaalp M, Kaynar Ö, Tekçe E, Aksakal A, Bayram B
Tarragon (Artemisia Dracunculus L.) Could Alleviate Negative Effects of Stocking Density in Laying Hens
Table 1 - Composition of experimental diet.

\begin{tabular}{|c|c|}
\hline Ingredients & $\mathrm{g} / \mathrm{kg}$ \\
\hline Corn & 352.40 \\
\hline Triticale & 175.00 \\
\hline Wheat & 75.00 \\
\hline Soybean meal, 340 g CP/kg & 114.60 \\
\hline Sunflower meal, $330 \mathrm{~g} \mathrm{CP/kg}$ & 103.60 \\
\hline Hazelnut, $420 \mathrm{~g} \mathrm{CP} / \mathrm{kg}$ & 35.00 \\
\hline Corn gluten meal, $600 \mathrm{~g} \mathrm{CP} / \mathrm{kg}$ & 25.00 \\
\hline Vegetable oil & 8.30 \\
\hline Limestone & 95.50 \\
\hline Dicalcium phosphate & 7.20 \\
\hline $\mathrm{NaCl}$ & 3.20 \\
\hline Premix & 2.50 \\
\hline L-Lysine $\mathrm{HCl}$ & 1.50 \\
\hline Naturabind-S & 1.20 \\
\hline \multicolumn{2}{|l|}{ Chemical analysis of feed } \\
\hline Crude matter & 892.20 \\
\hline Crude protein & 167.50 \\
\hline Ether extract & 46.60 \\
\hline Crude fiber & 52.90 \\
\hline Crude ash & 131.70 \\
\hline Starch & 339.90 \\
\hline \multicolumn{2}{|c|}{ Calculated contents of feed $(\ldots / \mathrm{kg})$} \\
\hline Metabolizable energy, MJ² & 11.45 \\
\hline Methionine, g & 3.70 \\
\hline Methionine + Cystine, $g$ & 6.70 \\
\hline Lysine, $g$ & 7.50 \\
\hline Linoleic acid, g & 22.10 \\
\hline $\mathrm{Ca}, \mathrm{g}$ & 39.00 \\
\hline Available P, g & 3.50 \\
\hline $\mathrm{Na}, \mathrm{g}$ & 1.50 \\
\hline \multicolumn{2}{|c|}{$\begin{array}{l}\text { 'Premix provided per kilogram of diet: vitamin } \mathrm{A} \text { (retinyl acetate), } 6.7 \mathrm{mg} \text {; vitamin } \mathrm{D}_{3} \\
\text { (cholecalciferol), } 1.6 \mathrm{mg} \text {; vitamin } \mathrm{E} \text { ( } \alpha \text {-tocopherol), } 30 \mathrm{mg} \text {; vitamin } \mathrm{K}_{3} \text { (menadione), } \\
2.5 \mathrm{mg} \text {; vitamin } \mathrm{B}_{1} \text { (thiamine), } 3 \mathrm{mg} \text {; vitamin } \mathrm{B}_{2} \text { (riboflavin), } 7 \mathrm{mg} \text {; vitamin } \mathrm{B}_{3} \text { (niacin), } \\
40 \mathrm{mg} \text {; vitamin } \mathrm{B}_{5} \text { (Ca-D-pantothenate), } 8 \mathrm{mg} \text {; vitamin } \mathrm{B}_{6} \text { (pyridoxine), } 4 \mathrm{mg} \text {; vitamin } \\
\mathrm{B}_{8} \text { (D-biotin), } 0.1 \mathrm{mg} \text {; vitamin } \mathrm{B}_{9} \text { (folic acid), } 1 \mathrm{mg} \text {; vitamin } \mathrm{B}_{12} \text { (cyanocobalamin), } 0.02 \\
\mathrm{mg} \text {; vitamin C (ascorbic acid), } 50 \mathrm{mg} \text {; choline chloride, } 125 \mathrm{mg} ; \mathrm{Mn}, 80 \mathrm{mg} \text {; Fe, } 60 \mathrm{mg} \text {; } \\
\mathrm{Zn}, 60 \mathrm{mg} ; \mathrm{Cu}, 5 \mathrm{mg} \text {; Co, } 0.10 \mathrm{mg} \text { Se, } 0.15 \mathrm{mg} \text {. }\end{array}$} \\
\hline $\begin{array}{l}{ }^{2} \text { Metabolisable energy (ME) is calcul } \\
\text { (1991). }\end{array}$ & d provided by TSE \\
\hline
\end{tabular}

\section{Performance and Egg Quality Parameters}

Weight gain (WG), feed intake ( $\mathrm{Fl})$ and feed conversion ratio, FCR were determined every two weeks; the damaged egg ratio (DER), average egg weight (AEW) and egg weight (EW) were determined daily. In order to determine such egg quality parameters such as yolk height $(\mathrm{YH})$, yolk color index $(\mathrm{YCl})$, Haugh unit (HU), shell strength (SS), shell thickness (ST), shape index (SI) and shell weight (SW), three random egg samples were taken from each replication (12 from each group; total 96) at 4 and $8 \mathrm{w}$. After the samples were kept at room temperature for 24 hours, they were subjected to analysis with an advanced laser light method branded NABEL DET6000.

\section{Serum CORT, IgG, TAS and TOS}

At the end of the experiment, a total of 80 samples, 10 from each group, were taken for blood, yolk and tissue analysis. CORT, TAS, TOS and IgG in the blood; malondialdehyde (MDA) in the blood, yolk and liver; and E. coli and total mesophilic aerobic bacteria in the small intestine were determined. At the end of the experimental period, serum was separated by centrifuging approximately $7 \mathrm{ml}$ blood samples taken from the vena jugularis after 12-hours of fasting, and kept at $-82^{\circ} \mathrm{C}$ until the analysis. CORT concentrations were determined using commercially available radio immune assay sets (Byk-Sangtec Diagnostica, Dietzenbach-Germany; Immulite 2000, DPC, LA) (Sahin et al., 2003). Serum IgG concentrations were determined using the ELISA method, as mentioned by Li et al. (2000). linearity of the standard IgG was calculated using the Excel program. Serum TOS was measured spectrophotometrically and calibrated with hydrogen peroxide (Erel, 2005). Serum TAS level was measured using the colorimetric method developed by Erel (2004). The eggs that were selected for yolk MDA analysis were stored for 21 days at $+6{ }^{\circ} \mathrm{C}$, after which, 10 samples were taken from the liver and yolk, and stored until the time of analysis at $-82{ }^{\circ} \mathrm{C}$ after being homogenized. The MDA analyses were carried out based on the method put forward by .

\section{Small Intestine E. coli and Total Mesophilic Aerobic Bacteria}

A total of 10 small intestine content samples were collected from each experiment group for total mesophilic aerobic bacteria and E.coli counts. The total E.coli and mesophilic aerobic bacteria counts reproduced at the end of the incubation period were determined in line with.

\section{Statistical analysis}

The data was subjected to an analysis of variance (General Linear Model procedure) with a completely randomized design using SPSS software (2002). Data on the egg quality parameters was analyzed according to the $2 \times 2 \times 4$ factorial design. A Duncan multiple range test was applied to compare the effects of the different doses of tarragon.

\section{RESULTS}

\section{Performance and Egg Quality Criteria}

Effects on performance of SD and of different doses of tarragon in the diet are given in Table 2. SD and 
Table 2 - The effects of tarragon supplementation to diet on performance parameters.

\begin{tabular}{|c|c|c|c|c|c|c|c|c|c|}
\hline$S$ & $\mathrm{~T}, \mathrm{~g} / \mathrm{kg}$ feed & BWBE, $g$ & BWEE, g & $W G, g$ & $\mathrm{Fl}, \mathrm{g} / \mathrm{hen} / \mathrm{d}$ & $\mathrm{FCR}, \mathrm{kg} / \mathrm{kg}$ & $E P, \%$ & AEW, g & $\mathrm{DE}, \%$ \\
\hline \multirow{5}{*}{$N$} & 0 & 1617 & 2123 & 506 & $127.0^{a}$ & $2.59^{b}$ & $73.5^{b c}$ & 66.8 & $4.42^{b c}$ \\
\hline & 1.2 & 1659 & 2088 & 429 & $123.5^{b}$ & $2.38^{\mathrm{ab}}$ & $78.5^{\mathrm{ab}}$ & 66.4 & $3.77^{\mathrm{ab}}$ \\
\hline & 6 & 1621 & 2050 & 429 & $124.5^{b}$ & $2.26^{a}$ & $84.0^{a}$ & 65.9 & $3.07^{a}$ \\
\hline & 12 & 1662 & 2107 & 445 & $127.5^{a}$ & $2.55^{b}$ & $76.3^{b c}$ & 65.8 & $4.17^{b c}$ \\
\hline & 0 & 1659 & 2133 & 473 & $115.8^{\mathrm{cd}}$ & $2.57^{b}$ & $71.3^{c}$ & 63.4 & $4.85^{c}$ \\
\hline \multirow{4}{*}{$\mathrm{H}$} & 1.2 & 1661 & 2058 & 398 & $113.8^{d}$ & $2.19^{a}$ & $79.0^{\mathrm{ab}}$ & 65.9 & $4.02^{\mathrm{abc}}$ \\
\hline & 6 & 1629 & 2004 & 374 & $114.3^{\mathrm{cd}}$ & $2.39^{a b}$ & $75.0^{b c}$ & 63.9 & $3.66^{\mathrm{ab}}$ \\
\hline & 12 & 1646 & 2000 & 354 & $116.5^{c}$ & $2.43^{\mathrm{ab}}$ & $73.3^{b c}$ & 65.6 & $4.51^{\mathrm{bc}}$ \\
\hline & SEM & 9 & 15 & 18 & 1.0 & 0.04 & 0.04 & 0.4 & 0.13 \\
\hline \multirow{2}{*}{$S$} & $\mathrm{~N}$ & 1640 & 2092 & 453 & $125.6^{\mathrm{a}}$ & 2.44 & $78.1^{\text {a }}$ & 66.2 & 3.86 \\
\hline & $\mathrm{H}$ & 1649 & 2049 & 400 & $115.1^{\mathrm{b}}$ & 2.40 & $74.6^{b}$ & 64.7 & 4.26 \\
\hline \multirow{5}{*}{$\mathrm{T}, \mathrm{g} / \mathrm{kg}$ feed } & 0 & 1638 & 2128 & 490 & $121.4^{a}$ & $2.58^{c}$ & $72.4^{b}$ & 65.1 & $4.64^{c}$ \\
\hline & 1.2 & 1660 & 2073 & 413 & $118.6^{b}$ & $2.28^{a}$ & $78.8^{a}$ & 66.2 & $3.90^{\mathrm{ab}}$ \\
\hline & 6 & 1625 & 2027 & 402 & $119.4^{b}$ & $2.33^{\mathrm{ab}}$ & $79.5^{a}$ & 64.9 & $3.36^{a}$ \\
\hline & 12 & 1654 & 2053 & 400 & $122.0^{\mathrm{a}}$ & $2.49^{\mathrm{bc}}$ & $74.8^{\mathrm{ab}}$ & 65.7 & $4.34^{\mathrm{bc}}$ \\
\hline & & \multicolumn{8}{|c|}{$p$-value } \\
\hline$S$ & & NS & NS & NS & 0.01 & NS & 0.05 & NS & NS \\
\hline $\mathrm{T}$ & & NS & NS & NS & 0.01 & 0.01 & 0.01 & NS & 0.01 \\
\hline$S \times T$ & & NS & NS & NS & NS & NS & NS & NS & NS \\
\hline
\end{tabular}

$\mathrm{S}$, stocking; $\mathrm{N}$, normal; $\mathrm{H}$, high, $\mathrm{T}$, tarragon; BWBE, body weight at the beginning of the experiment; BWEE, Body weight at the end of the experiment; WG, weight gain; $\mathrm{Fl}$, feed intake;

EP, egg production; AEW, average egg weight; FCR, feed conversion ratio; DE, damaged egg; NS, not significant.

a-d, Values within a column with different superscripts differ significantly (Duncan's test).

tarragon doses had no effect on body weight between the beginning and end of the test, WG and AEW $(p>0.05)$. An increase in SD had no effect on FCR and $\operatorname{DER}(p>0.05)$, but decreased the daily FI $(p<0.01)$ and EP $(p<0.05)$. T1.2 and T6 diets decreased FI and DER $(p<0.01)$ and improved FCR $(p<0.01)$.

The effects on egg quality characteristics of SD and different tarragon doses in the diet are given in Table 3. It was determined that age, SD and tarragon dietary supplementation had no significant effect on the $\mathrm{YH}, \mathrm{HU}, \mathrm{SS}, \mathrm{SI}$ or SW egg quality parameters. Age and SD had no effect on $\mathrm{YCI}(p>0.05)$, while $\mathrm{YCI}$ was decreased by tarragon supplementation $(p<0.01)$. The interactions of $\mathrm{D} \times \mathrm{S}$ and $\mathrm{D} \times \mathrm{S} \times \mathrm{T}$ on $\mathrm{YCl}$, on the other hand, were significant $(p<0.01)$, and SD and changes in the tarragon doses in the diet had no effect on ST ( $p>0.05)$, but decreased as the age increased $(p<0.05)$.

\section{Serum CORT, IgG, TAS and TOS}

The effect of SD and tarragon doses on serum CORT, IgG, TAS and TOS quantities are presented in Table 4. Serum CORT, which was high $(p<0.001)$ in HSD, decreased $(p<0.001)$ in a parallel with tarragon dietary supplementation. Furthermore the $\mathrm{S} \times \mathrm{T}$ interaction on serum CORT was significant $(p<0.001)$. SD had no effect on the serum $\lg G(p>0.05)$. T6 and T12 increased the serum IgG more than in the control, and the T12 effect was higher $(p<0.001)$. HSD decreased serum TAS $(p<0.01)$, and tarragon supplementation increased the TAS amount only numerically ( $p>0.05)$. While SD increased serum TOS $(p<0.001)$, the tarragon doses decreased this parameter $(p<0.001)$. T12 was more effective $(p<0.05)$ in decreasing serum TOS when compared to T1.2 and T6.

\section{Serum, Liver and Egg MDA}

The effects of SD and tarragon doses on serum, liver and egg MDA quantities are presented in Table 5 . HSD raised the MDA in the serum $(p<0.001)$, liver $(p<0.05)$ and egg yolk $(p<0.001)$. T6 and T12 diets decreased serum MDA. All doses of tarragon decreased the liver MDA $(p<0.001)$, and T6 and T12 were more effective than T1.2 on this parameter. Moreover $\mathrm{S} \times \mathrm{T}$ interaction was significant in the quantity of liver MDA $(p<0.05)$. The T6 and T12 diets decreased the yolk MDA $(p<0.001)$, and T12 was more effective on the yolk MDA when compared to T6 $(p<0.05)$.

\section{Small Intestine E. coli and Total Mesophilic Aerobic Bacteria}

The effects of SD and tarragon doses on E. coli and total mesophilic aerobic bacteria counts in the small intestine are presented in Table 5. HSD raised the counts of $E$. coli and the total Mesophilic Aerobic Bacteria in the small intestine $(p<0.001)$. Tarragon doses decreased $E$. coli only numerically $(p>0.05)$; and T6 and T12 decreased significantly $(p<0.05)$ the total mesophilic aerobic bacteria count when compared to the control. 
Table 3 - The effect of tarragon supplementation to diet on the egg shell quality parameters.

\begin{tabular}{|c|c|c|c|c|c|c|c|c|c|c|}
\hline D & $S$ & $\mathrm{~T}, \mathrm{~g} / \mathrm{kg}$ feed & EW, g & $\mathrm{YH}, \mathrm{mm}$ & $\mathrm{YCl}$ & $\mathrm{HB}$ & SS, Kgf & $\mathrm{ST}, \mathrm{mm}$ & $\mathrm{SI}$ & SW, g \\
\hline \multirow{8}{*}{28} & \multirow{4}{*}{ N } & 0 & $65.8^{\mathrm{ab}}$ & 6.3 & $9.7^{a}$ & 75.7 & $2.19^{a b}$ & $0.37^{\mathrm{ab}}$ & 73.6 & $8.0^{\mathrm{ab}}$ \\
\hline & & 1.2 & $64.4^{\mathrm{ab}}$ & 6.1 & $6.8^{b c}$ & 74.1 & $2.43^{a}$ & $0.38^{\mathrm{ab}}$ & 73.4 & $8.0^{a b}$ \\
\hline & & 6 & $65.3^{\mathrm{ab}}$ & 6.1 & $6.6^{b c}$ & 74.3 & $2.46^{a}$ & $0.38^{\mathrm{ab}}$ & 74.8 & $8.1^{\mathrm{a}}$ \\
\hline & & 12 & $64.5^{\mathrm{ab}}$ & 5.9 & $6.6^{b c}$ & 73.3 & $2.34^{\mathrm{ab}}$ & $0.34^{\mathrm{ab}}$ & 73.9 & $7.8^{\mathrm{ab}}$ \\
\hline & \multirow{4}{*}{$\mathrm{H}$} & 0 & $61.9^{\mathrm{ab}}$ & 6.2 & $7.5^{b c}$ & 76.9 & $2.38^{a}$ & $0.36^{a b}$ & 74.4 & $7.7^{\mathrm{ab}}$ \\
\hline & & 1.2 & $65.4^{\mathrm{ab}}$ & 6.6 & $7.1^{b c}$ & 77.5 & $2.42^{\mathrm{a}}$ & $0.39^{a}$ & 73.5 & $7.9^{a b}$ \\
\hline & & 6 & $61.3^{b}$ & 5.7 & $6.6^{b c}$ & 71.5 & $2.35^{\mathrm{ab}}$ & $0.38^{\mathrm{ab}}$ & 74.1 & $7.7^{\mathrm{ab}}$ \\
\hline & & 12 & $63.3^{\mathrm{ab}}$ & 6.0 & $7.6^{b c}$ & 74.9 & $2.39^{a}$ & $0.35^{\mathrm{ab}}$ & 74.3 & $7.7^{\mathrm{ab}}$ \\
\hline \multirow{9}{*}{56} & \multirow{4}{*}{ N } & 0 & $68.2^{a}$ & 5.6 & $7.5^{\mathrm{bc}}$ & 71.7 & $2.49^{a}$ & $0.33^{b}$ & 73.9 & $7.6^{\mathrm{ab}}$ \\
\hline & & 1.2 & $65.3^{\mathrm{ab}}$ & 6.4 & $6.8^{b c}$ & 76.9 & $2.40^{\mathrm{a}}$ & $0.34^{\mathrm{ab}}$ & 73.3 & $7.7^{\mathrm{ab}}$ \\
\hline & & 6 & $61.8^{\mathrm{ab}}$ & 6.1 & $5.8^{c}$ & 73.8 & $2.33^{\mathrm{ab}}$ & $0.35^{\mathrm{ab}}$ & 73.7 & $7.6^{\mathrm{ab}}$ \\
\hline & & 12 & $65.2^{\mathrm{ab}}$ & 5.7 & $6.7^{b c}$ & 71.7 & $2.37^{a}$ & $0.36^{\mathrm{ab}}$ & 73.8 & $7.2^{\mathrm{b}}$ \\
\hline & \multirow{4}{*}{$\mathrm{H}$} & 0 & $64.8^{\mathrm{ab}}$ & 5.8 & $10.4^{a}$ & 73.4 & $1.97^{b}$ & $0.34^{\mathrm{ab}}$ & 74.0 & $7.4^{\mathrm{ab}}$ \\
\hline & & 1.2 & $65.4^{\mathrm{ab}}$ & 6.4 & $6.4^{\mathrm{bc}}$ & 77.1 & $2.38^{a}$ & $0.36^{\mathrm{ab}}$ & 73.1 & $8.0^{\mathrm{ab}}$ \\
\hline & & 6 & $62.1^{\mathrm{ab}}$ & 5.6 & $5.8^{b c}$ & 73.1 & $2.43^{a}$ & $0.36^{\mathrm{ab}}$ & 74.1 & $8.0^{\mathrm{ab}}$ \\
\hline & & 12 & $65.8^{\mathrm{ab}}$ & 5.6 & $6.6^{b c}$ & 70.4 & $2.04^{\mathrm{a}}$ & $0.35^{\mathrm{ab}}$ & 72.9 & $7.7^{\mathrm{ab}}$ \\
\hline & & SEM & 0.5 & 0.1 & 0.2 & 0.8 & 0.03 & 0.01 & 0.2 & 0.1 \\
\hline \multirow[b]{2}{*}{ D } & & 28 & 64.0 & 6.1 & 7.3 & 74.8 & 2.37 & $0.37^{a}$ & 74.0 & 7.9 \\
\hline & & 56 & 64.8 & 5.9 & 7.1 & 73.5 & 2.35 & $0.35^{b}$ & 73.6 & 7.6 \\
\hline \multirow{2}{*}{$S$} & & $\mathrm{~N}$ & 65.0 & 6.0 & 7.0 & 73.9 & 2.38 & 0.36 & 73.8 & 7.7 \\
\hline & & $\mathrm{H}$ & 63.7 & 6.0 & 7.4 & 74.3 & 2.34 & 0.36 & 73.8 & 7.7 \\
\hline \multirow{12}{*}{$\mathrm{T}, \mathrm{g} / \mathrm{kg}$ feed } & & 0 & 65.1 & 6.0 & $8.8^{a}$ & 74.4 & 2.26 & 0.35 & 74.0 & 7.7 \\
\hline & & 1.2 & 65.1 & 6.3 & $6.8^{b}$ & 76.4 & 2.41 & 0.37 & 73.3 & 7.9 \\
\hline & & 6 & 62.6 & 5.8 & $6.4^{b}$ & 73.2 & 2.39 & 0.37 & 73.2 & 7.8 \\
\hline & & 12 & 64.7 & 5.8 & $6.9^{b}$ & 72.6 & 2.37 & 0.35 & 73.7 & 7.6 \\
\hline & \multicolumn{10}{|c|}{$p$-value } \\
\hline & & & NS & NS & NS & NS & NS & 0.05 & NS & NS \\
\hline & & & NS & NS & NS & NS & NS & NS & NS & NS \\
\hline & & & NS & NS & 0.01 & NS & NS & NS & NS & NS \\
\hline & & & NS & NS & NS & NS & NS & NS & NS & NS \\
\hline & & & NS & NS & NS & NS & NS & NS & NS & NS \\
\hline & & & NS & NS & NS & NS & NS & NS & NS & NS \\
\hline & & & NS & NS & 0.01 & NS & NS & NS & NS & NS \\
\hline
\end{tabular}

D, day; S, stocking; N, normal; H, high, T, tarragon; EW, egg weight; YH, yellow height; YCl; yellow color index NS, not significant; HB, haugh birimi; SS, shell strength; ST, shell thickness; SI, shape index; SW, shell weight. ${ }^{\text {acc, }}$

Values within a column with different superscripts differ significantly (Duncan's test).

\section{DISCUSSION}

\section{Performance}

In the present study, SD and tarragon doses had no effect on body weight between the beginning and end of the test, WG and AEW ( $p>0.05)$. There are also studies indicating that the HSD has a negative effect on the WG (Onbaşılar \& Aksoy, 2005; Nahashon et al., 2006; Sahin et al., 2007; Sarica et al., 2008) and has no effect as in the present study (Jalal et al., 2006; Onbaşılar et al., 2009; Fidan, 2010). The differences between the results of the present study and those in literature could be attributed to the lack of standardization of area allocated per hen. In the present study, the addition of $40 \%$ more space per animal to the HSD group than in the NSD group was not sufficient to affect weight parameters ( $p>0.05)$. It is stated that the dietary supplementation of $1 \%$ Artemisia sieberi (Khalaji et al., 2011), 2 and 4\% Artemisia annua (Cherian et al., 2013) and 0.4\% Artemisia dracunculus to broilers (Gharetappe et al., 2015) had no effect on WG. (Hosseinzadeh \& Moghaddam, 2014) reported that the dietary supplementation of 0.125 and $0.25 \%$ of Artemisia dracunculus did not affect WG, while a $0.5 \%$ dose decreased it. Kheirabadi et al. (2014) reported that the incorporation of $5 \mathrm{mg} / \mathrm{kg}$ of Artemisia sieberi granulated extract (GEAS) into the diet reduced live weight at 42 days when compared to control group. It was reported that the incorporation of 10 and $20 \%$ of Artemisia annua (Brisibe et al., 2008); 0.5, 1 and $1.5 \%$ of Artemisia annua leaf powder with 2000 and 4000 ppm methanolic extract (Gholamrezaie et al., 2013); $1.5 \%$ of Artemisia annua (Drăgan et al., 2014); and 100, 150 and $200 \mathrm{~g} / \mathrm{kg}$ of Artemisia 
Table 4 - The effect of the tarragon supplementation on the blood serum CORT, IgG, TAS and TOS.

\begin{tabular}{|c|c|c|c|c|c|}
\hline$S$ & $\mathrm{~T}, \mathrm{~g} / \mathrm{kg}$ feed & CORT nmol/L & $\operatorname{lgG} \mathrm{mg} / \mathrm{dL}$ & TAS $\mu \mathrm{mol} / \mathrm{L}$ & TOS $\mu \mathrm{mol} / \mathrm{L}$ \\
\hline \multirow{4}{*}{$N$} & 0 & $43^{e}$ & $1.09 \mathrm{bc}$ & $761^{\mathrm{ab}}$ & $21.9^{d}$ \\
\hline & 1.2 & $39^{e}$ & $1.13^{b c}$ & $776^{a b}$ & $19.1^{\mathrm{e}}$ \\
\hline & 6 & $39^{e}$ & $1.20^{\mathrm{ab}}$ & $787^{\mathrm{ab}}$ & $19.8^{\text {de }}$ \\
\hline & 12 & $37^{e}$ & $1.30^{\mathrm{a}}$ & $798^{a}$ & $18.4^{\mathrm{e}}$ \\
\hline \multirow{4}{*}{$\mathrm{H}$} & 0 & $102^{\mathrm{a}}$ & $1.08^{c}$ & $710^{b}$ & $30.8^{a}$ \\
\hline & 1.2 & $93^{b}$ & $1.13^{b c}$ & $728^{\mathrm{ab}}$ & $28.9^{a b}$ \\
\hline & 6 & $71^{c}$ & $1.16^{\mathrm{bc}}$ & $735^{\mathrm{ab}}$ & $27.7^{\mathrm{bc}}$ \\
\hline & 12 & $61^{d}$ & $1.20^{\mathrm{ab}}$ & $749^{a b}$ & $26.1^{c}$ \\
\hline SEM & SEM & 3 & 0.01 & 9 & 0.6 \\
\hline \multirow{2}{*}{$S$} & $\mathrm{~N}$ & $40^{b}$ & 1.18 & $781^{a}$ & $19.8^{\mathrm{b}}$ \\
\hline & $\mathrm{H}$ & $82^{\mathrm{a}}$ & 1.14 & $730^{b}$ & $28.4^{a}$ \\
\hline \multirow{4}{*}{$\mathrm{T}$} & 0 & $73^{a}$ & $1.08^{c}$ & 735 & $26.4^{\mathrm{a}}$ \\
\hline & 1.2 & $66^{b}$ & $1.13^{b c}$ & 752 & $24.0^{b}$ \\
\hline & 6 & $55^{c}$ & $1.18^{b}$ & 761 & $23.7^{b c}$ \\
\hline & 12 & $49^{d}$ & $1.25^{\mathrm{a}}$ & 773 & $22.3^{c}$ \\
\hline & & \multicolumn{4}{|c|}{$p$-values } \\
\hline$S$ & & 0.001 & 0.109 & 0.004 & 0.001 \\
\hline $\mathrm{T}$ & & 0.001 & 0.001 & 0.467 & 0.001 \\
\hline$S \times T$ & & 0.001 & 0.541 & 1.000 & 0.550 \\
\hline
\end{tabular}

S, stocking; N, normal; H, high; T, tarragon; CORT, corticosterone; TIgG, total immunoglobulin G; TAS, total antioksidant of serum; TOS, total oxidant of serum; SEM, standart error of the mean.

a-e, Values within a column with different superscripts differ significantly (Duncan's test).

absinthium (Kostadinović et al., 2015) into broiler diets increased WG. In the present study, the incorporation of different levels of tarragon into diets of laying hens had no significant effect on live weight or live weight gain ( $p>0.05$ ).

In addition to the findings that SD had no effect on the Fl of laying hens (Anderson et al., 2004; Simsek \&
Kilic, 2006), similar findings to those of our study that it decreased Fl have been reported $(p<0.01)$ (Sohail et al., 2004; Jalal et al., 2006; Sahin et al., 2007; Onbaşılar et al., 2009; Fidan, 2010; Mirfendereski \& Jahanian, 2015). It is considered that the reduction in feeder space per bird in HSD is the main factor reducing FI. T1.2 and $\mathrm{T} 6$ diets reduced $\mathrm{FI}$ when compared to the control

Table 5 - The effect of the tarragon supplementation on the MDA and intestine microorganisms.

\begin{tabular}{|c|c|c|c|c|c|c|}
\hline$S$ & $\mathrm{~T}, \mathrm{~g} / \mathrm{kg}$ feed & SMDA mmol/L & LMDA mmol/L & EMDA mmol/L & E. coli Log, TBX & TMAB Log, PCA \\
\hline \multirow{4}{*}{$N$} & 0 & $3.60^{c}$ & $95^{b c}$ & $221^{\mathrm{cd}}$ & $3.65^{b c}$ & $6.2^{\mathrm{bcd}}$ \\
\hline & 1.2 & $3.49^{c}$ & $94^{\mathrm{bc}}$ & $218^{\mathrm{cd}}$ & $3.61^{c}$ & $6.0^{\text {cd }}$ \\
\hline & 6 & $3.50^{c}$ & $91^{\mathrm{bcd}}$ & $216^{d}$ & $3.52^{c}$ & $5.9^{d}$ \\
\hline & 12 & $3.46^{c}$ & $85^{d}$ & $211^{\mathrm{d}}$ & $3.42^{c}$ & $5.8^{d}$ \\
\hline \multirow{5}{*}{$\mathrm{H}$} & 0 & $4.25^{a}$ & $107^{a}$ & $254^{a}$ & $4.05^{\mathrm{a}}$ & $6.8^{a}$ \\
\hline & 1.2 & $3.99^{\mathrm{ab}}$ & $96^{b}$ & $248^{a}$ & $4.03^{a}$ & $6.7^{\mathrm{ab}}$ \\
\hline & 6 & $3.73^{\mathrm{bc}}$ & $90^{\mathrm{bcd}}$ & $237^{b}$ & $3.94^{\mathrm{ab}}$ & $6.4^{\mathrm{abc}}$ \\
\hline & 12 & $3.79^{b c}$ & $88^{\mathrm{cd}}$ & $227^{b c}$ & $3.92^{\mathrm{ab}}$ & $6.4^{\mathrm{abc}}$ \\
\hline & SEM & 0.05 & 1 & 2 & 0.04 & 0.1 \\
\hline \multirow{2}{*}{$S$} & $N$ & $3.51^{b}$ & $91^{\mathrm{b}}$ & $217^{b}$ & $3.55^{\mathrm{b}}$ & $6.0^{\mathrm{b}}$ \\
\hline & $\mathrm{H}$ & $3.94^{\mathrm{a}}$ & $95^{a}$ & $242^{a}$ & $3.98^{a}$ & $6.6^{a}$ \\
\hline \multirow{4}{*}{$\mathrm{T}$} & 0 & $3.92^{\mathrm{a}}$ & $101^{a}$ & $237^{a}$ & 3.85 & $6.5^{a}$ \\
\hline & 1.2 & $3.74^{\mathrm{ab}}$ & $95^{b}$ & $233^{\mathrm{ab}}$ & 3.82 & $6.3^{a b}$ \\
\hline & 6 & $3.61^{b}$ & $90^{c}$ & $227^{b}$ & 3.73 & $6.1^{b}$ \\
\hline & 12 & $3.62^{b}$ & $87^{c}$ & $219^{c}$ & 3.67 & $6.1^{\mathrm{b}}$ \\
\hline & & & & $p$-values & & \\
\hline$S$ & & 0.001 & 0.011 & 0.001 & 0.001 & 0.001 \\
\hline $\mathrm{T}$ & & 0.019 & 0.001 & 0.001 & 0.280 & 0.040 \\
\hline$S \times T$ & & 0.234 & 0.022 & 0.056 & 0.972 & 0.976 \\
\hline
\end{tabular}

S, stocking; N, normal; H, high; T, tarragon; STP, serum total protein; LTP, liver total protein; SMDA, serum malondialdehyde; LMDA, liver malondialdehyde; EMDA, egg malondialdehyde; $T M A B$, total mesophilic aerobic bacteria; SEM, standart error of the mean.

a-d, Values within a column with different superscripts differ significantly (Duncan's test). 
group $(p<0.01)$, while the T12 diet had no effect on FI ( $p>0.05)$ in the present study, which concurs with the findings of Gholamrezaie et al. (2013), who reported that the incorporation of Artemisia annua extract and leaf powder mixture into broiler diets reduced Fl. The incorporation of Artemisia sieberi (Khalaji et al., 2011), Artemisia dracunculus (Gharetappe et al., 2015; Hosseinzadeh \& Moghaddam, 2014), Artemisia annua (Cherian et al., 2013) and GEAS (Kheirabadi et al., 2014) into broiler diets did not affect $\mathrm{Fl}$, although Brisibe et al. (2008) reported that the incorporation of Artemisia annua leaves increased $\mathrm{Fl}$.

There have been several studies indicating that SD affected (Onbaşılar et al., 2009), had no effect (Anderson et al., 2004; Simsek \& Kilic, 2006; Fidan, 2010; Mirfendereski \& Jahanian, 2015)) or improved (Sahin et al., 2007) FCR in laying hens. In the present study, HSD had no effect on FCR $(p>0.05)$, while T1.2 and T6 diets improved FCR when compared to control diet $(p<0.05)$. There have been studies that the incorporation of different Artemisia species into the diets of broilers improved FCR (Gholamrezaie et al., 2013; Drăgan et al., 2014; Kheirabadi et al., 2014; Kostadinović et al., 2015) or not affected (Khalaji et al., 2011; Cherian et al., 2013; Gharetappe et al., 2015). Hosseinzadeh \& Moghaddam (2014) reported that the incorporation of $0.5 \%$ tarragon into the diet affected FCR negatively, while lower levels $(0.125 \%$ and $0.25 \%$ ) had no effect.

In our study, it was found that HSD reduced EP as in previous studies (Onbaşılar \& Aksoy, 2005; Jalal et al. 2006; Sarica et al., 2008; Onbaşılar et al., 2009; Fidan, 2010; Mirfendereski \& Jahanian, 2015) $(p<0.05)$, and reduced feeder space per bird (Onbaşılar \& Aksoy, 2005; Jalal et al., 2006) and stress conditions caused by high stocking densities (Sarica et al., 2008; Mirfendereski \& Jahanian, 2015; ) were found to be responsible for this result. Mirfendereski \& Jahanian (2015) found a reduction of EP in HSD to be associated with blood CORT levels. In some studies, it was reported that SD had no effect on EP (Simsek \& Kilic, 2006; Sahin et al., 2007). Brisibe et al. (2008) reported that the incorporation of $20 \%$ Artemisia annua leaves into laying hen diets increased EP. It has further been reported that the incorporation of an extract composed of $70 \%$ pine needle and $30 \%$ Artemisia annua into laying hen diets (Li et al., 2016) improved EP. In the present study, the incorporation of tarragon into the diet increased EP in the T1.2 and T6 diets when compared to the control diet $(p<0.01)$. This improvement can be explained by the fact that tarragon, which has antioxidant properties, reduces serum CORT and TOS levels, thus reducing stress. It has further been reported that the incorporation of salvia officinalis, thymbra spicata, menthae piperitae extracts, vitamin E (Kaya \& Turgut, 2012) and Coriander Oil extract (Çiftci \& Macit, 2018) into laying hen diets increased EP, while Rosmarinus officinalis L. (Çimrin \& Demirel, 2016) incorporation did not affect EP.

It has also been reported that HSD reduced EP and increased AEW (Onbaşılar et al., 2009), while HSD reduced feeder space per bird, and thus AEW (Sohail et al., 2004; Sahin et al., 2007; Fidan, 2010). In addition, there have been studies reporting that increasing SD has no effect on AEW (Guesdon et al., 2006; Sarica et al., 2008; Mirfendereski \& Jahanian, 2015 ), as in the present study, or affected AEW (Sahin et al., 2007; Onbaşılar et al., 2009; Fidan, 2010). In the present study, the tarragon levels incorporated into the diet had no effect on AEW ( $p>0.05)$. It has been reported that the incorporation of Artemisia annua leaves into laying hen diets does not affect egg weight (Brisibe et al., 2008; Li et al., 2016), and that the incorporation of different plant extracts (Kaya \& Turgut, 2012; Çimrin \& Demirel, 2016) into laying hen diets did not affect or reduced (Çiftci \& Macit, 2018) egg weights. It has been stated that effects of phytogenic products on poultry performance data may differ depending on the origin, content and processing of the plant, as well as the species and age of the animal and environmental hygiene (Windisch et al., 2008).

In the present study, laying hens at 50 weeks of age were kept for 8 weeks. It is stated that it can be advantageous to provide antioxidant sources to old hens (Karaalp et al., 2018) whose egg shell quality may be more problematic due to many factors (Światkiewicz et al., 2010). Contrary to the finding that HSD causes a significant increases in DER (Guesdon et al., 2006), there have also been reports of no such effects on DER ( $p>0.05)$ (Sarica et al., 2008; Onbaşılar et al., 2009), similar to the present study. It has been found that the incorporation of an extract composed of pine needle and Artemisia annua into laying hen diets reduced DER, similar to the present study (Li et al., 2016). It has been further reported that the incorporation of different plant extracts into laying hen diets reduced (Kaya \& Turgut, 2012) or had no affect (Çimrin \& Demirel, 2016; Çiftçi \& Macit, 2018) on DER. In the present study, T1.2 and T6 reduced DER when compared to the control diet $(p<0.01)$.

\section{Egg Quality Criteria}

The advancement of the trial period (50-58 weeks of age) had no effect on any egg quality criteria other 
than ST ( $p>0.05)$. The increase in age caused a decrease in ST in the present study, concurring with the findings of and Onbassilar et al. (2018). In the present study, the fact that SD did not affect egg quality parameters was consistent with earlier studies (Sahin et al., 2007; Sarica et al. 2008; Fidan, 2010). In poultry, it was reported that SD did not affect egg YH (Karabayir et al., 2010), SS (Sahin et al., 2007; Sarica et al., 2008; Karabayir et al., 2010), ST (Onbaşılar \& Aksoy, 2005; Nahashon et al., 2006; Sahin et al., 2007; Sarica et al., 2008; Fidan, 2010), SI (Sarica et al., 2008; Fidan, 2010) or SW (Sahin et al., 2007; Karabayir et al., 2010). That said, it has been reported that SD has different effects on parameters such as YCl (Sarica et al., 2008; Fidan, 2010) and HU (Nahashon et al., 2006; Sahin et al., 2007; Sarica et al., 2008; Fidan, 2010). It has been described that some antioxidant components of plants can improve calcium accumulation in the uterus, and thus increases shell weight and thickness (Ramírez-Tortosa et al., 1999). Our study has shown that the incorporation of tarragon into the diet has no effect on egg quality parameters, aside from reducing $\mathrm{YCI}(p<0.01)$. Li et al. (2016) reported that the incorporation of an extract composed of pine needle and Artemisia annua into laying hen diets did not affect EW, ST, HU, SS or SI. The increase in tarragon levels darkened the color of the diet, which had an unexpected effect on the egg yolk, but the cause of this could not be understood.

\section{Serum CORT, IgG, TAS and TOS}

Results of the present study showed that HSD, which is a social stressor affected some stress parameters (CORT, TAS, TOS) negatively $(p<0.05)$. In laying hens, it was detected that HSD lead to an increase in the blood corticosteroid level (Mirfendereski \& Jahanian, 2015). The glucocorticoids (cortisol and corticosterone) released by HPA with the effect of stressors when the animal is under stress are known to be immunosuppressive, and inhibit the production and effect of antibodies, deteriorate lymphocyte function and cause leukocyte proliferation (MUnck et al., 1984). Sohail et al. (2011) described that stress increases total oxidants and antioxidants in broiler serum. However, increases in serum antioxidants depending on the severity and duration of stressors is a controversial issue. Accordingly, in the present study, HSD increased serum CORT and TOS $(p<0.05)$, but reduced TAS $(p<0.05)$. The reduction in serum TAS concentration is considered to be related to the severity and duration of stressors (24 hours/day in this study) as well as the use of serum TAS in sweeping away the free radicals that are formed due to the oxidative stress that occurs.
The increases in the levels of tarragon, which contains antioxidant substances (Kordali et al., 2005), as well as the continuous overall reduction of serum CORT and TOS (first reduction in the T1.2 diet) $(p<0.05)$, the increase in serum IgG (first increase in T6 diet) $(p<0.05)$ and the fact that it does not affect serum TAS levels ( $p>0.05$ ) confirm our finding.

It is being suggested that antioxidant substances regulate corticosteroid synthesis in the adrenal glands and improve certain immune responses significantly (Gholamrezaie et al., 2013; Pardue \& Thaxton 1984). High egg production (physiological stress) often causes a degeneration of lymphoid organs (Gray et al., 1989) and the suppression of humoral and cell-mediated immune response (Murray et al., 1987). Furthermore, it has been noted that cell-mediated immunity drops after 45 weeks of age (Fahey \& Cheng, 2008). In the present study, the fact that SD did not affect serum $\operatorname{lgG}(p>0.05)$ suggests that reducing the space per bird is not sufficient to reduce this parameter. In addition, the T6 diet increased serum IgG $(p<0.05)$. The overall increase in serum $\lg G$ with the increase of tarragon levels in the diet $(p<0.001)$ can be associated with the immune-enhancing effect of tarragon. It is suggested that Artemisia annua leaf powder and methanolic extract affect performance by increasing the cellular and humoral immunity of broilers (Gholamrezaie et al., 2013). Furthermore, it has been reported that a $1 \%$ incorporation of Artemisia sieberi into broiler diets has no effect on plasma lymphocytes, eosinophils, basophils, primary or secondary antibody response against sheep red blood cells, but increases monocyte percentage (Khalaji et al., 2011). Gholamrezaie et al. (2013) reported that the effects of different natural products on the immune system were complicated, and that the stimulation of the lymphatic tissue of the digestive system was a direct effect, while the alteration of microbial population of the gastrointestinal system lumen was an indirect effect.

\section{Serum, Liver and Egg MDA}

In the present study, HSD, which is a social stressor, affected MDA, which is a lipid peroxidation indicator (in serum, liver, egg yolk), and some bacteria in the small intestine ( $E$. coli and total mesophilic aerobic bacteria counts) desirably $(p<0.05)$. Furthermore, HSD in the present study caused an increase in serum, liver and egg MDA $(p<0.05)$ by increasing serum CORT and reducing serum TAS, resulting from the increased stress in hens. There are studies reporting that the incorporation of plants and plant products containing antioxidant substances into laying hen diets reduced 
(Botsoglou et al., 1997; Botsoglou et al., 2005; Karaalp et al., 2018; Krause \& Ternes, 2000; Radwan et al., 2008) or did not affect (Galobart et al., 2001) egg yolk lipid peroxidation. Kostadinović et al. (2015) found that the incorporation of $20 \%$ Artemisia absinthium into the diet reduced blood MDA in broilers, while Cherian et al. (2013) reported that the incorporation of $2 \%$ and $4 \%$ Artemisia annua into broiler diets reduced MDA in the thigh and breast muscles of broilers. In the present study, serum, liver and egg MDA levels reduced $(p<0.05)$ in parallel to the reduction in serum CORT and TOS under the effect of the antioxidant substances found in the tarragon incorporated into the diets (Kordali et al., 2005). Serum and egg MDA started to reduce with the T6 diet, while liver MDA started to reduce with the T1.2 diet, when compared to the control diet $(p<0.05)$.

\section{Small Intestine E. coli and Total Mesophilic Aerobic Bacteria}

The findings of the present study suggest that the increase in E. coli and total mesophilic aerobic bacteria counts in the small intestine due to HSD are related to contamination $(p<0.001)$. In literature, the antimicrobial effects of artemisia species were mostly researched on coccidiosis, and these species were reported to be used for coccidiostatic purposes (Brisibe et al., 2008; De Almeida et al., 2012; Kostadinovic et al., 2012 Drăgan et al., 2014; Kheirabadi et al., 2014). Lopes-Lutz et al. (2008) reported that the oils of different Artemisia species are effective at different levels against microorganisms such as Escherichia coli, Staphylococcus epidermidis and Staphylococcus aureus. The fact that the incorporation of $1 \%$ Artemisia sieberi into broiler diets reduces cecal coliform and Escherichia coli populations (Khalaji et al., 2011), in addition to the findings in our study that the incorporation of different levels of tarragon into the diet has no effect on $E$. coli levels in the gut $(p>0.05)$, can be associated with the difference in artemisia species used in the studies. Furthermore, the presence of $6 \mathrm{~g}$ or more tarragon in the diet was found to affect the reduction of total mesophilic aerobic bacteria counts when compared to the control diet $(p<0.05)$.

\section{CONCLUSIONS}

With the incorporation of different levels of Artemisia dracunculus $\mathrm{L}$. into the diets of laying hens in the second production cycle and housed under different SDs, it was found that: HSD reduced FI and EP, the T1.2 and T6 kg diets reduced $\mathrm{FI}$ and DER, increased EP and improved
FCR. All levels of tarragon were found to reduce $\mathrm{YCl}$ levels. HSD increased serum CORT and TOS, as well as MDA levels in serum, liver and egg yolk, and reduced serum TAS, which was associated with the oxidative stress occurring resulting from the increasing social stress. The reduction of serum CORT and TOS (with all diets), serum and egg yolk MDA (T6 and T12 diets) and liver MDA (T1.2 diet) with the incorporation of tarragon into the diet was associated with the antioxidant substances found in tarragon. Serum IgG (with T6 and T12 g diets) increased with the incorporation of tarragon into the diet, indicating that tarragon has immune-enhancing substances. Total mesophilic aerobic bacteria counts reduced with the T6 and T12 diets, when compared to control diets, suggesting that tarragon contains a certain level of antibacterial substances.

\section{ACKNOWLEDGMENT}

This study was supported by Scientific Research Projects Coordinatorships of Bayburt University (Project No: 2017/01-69001-09) and Gumushane University (Project No: 17.B0121.02.01). This study was presented oraly at the $1^{\text {st }}$ International Erciyes Agriculture, Animal and Food Sciences Conference, AGANFOS-2019, 2427 April 2019, Kayseri/TURKEY. No potential conflict of interest was reported by the author(s). Thanks to the Aydın Doğan Foundation for their contribution

\section{REFERENCES}

Anderson KE., Davis GS, Jenkins PK, Carroll AS. Effects of bird age, density, and molt on behavioral profiles of two commercial layer strains in cages. Poultry Science 2004; 83(1):15-23.

AOAC - Association of Official Analysis Chemists International. Official methods of analysis of AOAC. Gaithersburg: AOAC International; 2007.

Ayaz MM, Akhtar M, Hussain I, Muhammad F, Haq AU. Immunoglobulin producing cells in chickens Immunized with Eimeria tenella gametocyte antigen vaccines. Veterinarni Medicina (Praha) 2008;53(4):207-213.

Botsoglou NA, Fletouris DJ, Papageorgiou GE, Vassilopoulos VN, Mantis AJ, Trakatellis AG. Rapid, sensitive, and specific thiobarbituric acid method for measuring lipid peroxidation in animal tissue, food, and feedstuff samples. Journal of Agricultural and Food Chemistry 1994;42(9):19311937.

Botsoglou NA, Yannakopoulos AL, Fletouris DL, Tserveni-Goussi AS, Fortomaris PD. Effect of dietary thyme on the oxidative stability of egg yolk. Journal of Agricultural and Food Chemistry 1997;45(10):37113716 .

Botsoglou N, Florou-Paneri P, Botsoglou E, Dotas V, Giannenas I, Koidis A, et al. The effect of feeding Rosemary, Oregano, Saffron and $\alpha$-tocopheryl acetate on hen performance and oxidative stability of eggs. South African Journal of Animal Sciences 2005;35(3):143-151.

Brisibe EA, Umoren UE, Owai PU, Brisibe F. Dietary Inclusion of dried artemisia annua leaves for management of coccidiosis and growth enhancement in chickens. African Journal of Biotechnology 2008;7(22):4083-4092. 
Carlander D, Kollberg H, Wejåker PE, Larsson A. Peroral ımmonutheraphy with yolk antibodies peroral Immunotheraphy with yolk antibodies for the prevention and treatment of enteric infections. Immunologic Research 2000;21(1):1-6.

Cherian G, Orr A, Burke IC, Pan W. Feeding Artemisia annua alters digesta ph and muscle lipid oxidation products in broiler chickens. Poultry Science 2013;92(4):1085-1090.

Conforti F, Statti G, Uzunov D, Menichini F. Comparative chemical composition and antioxidant activities of wild and cultivated Laurus nobilis L. leaves and Foeniculum vulgare subsp. Piperitum (Ucria) coutinho seeds. Biological and Pharmaceutical Bulletin 2006;29(10):2056-2064

Çiftçi ME, Macit M. Effect of coriander oil supplementation at different levels into diets of laying hens on performance, egg quality traits, yolk tbars values and some serum parameters. Alinteri Journel of Agriculture Sciences 2018;33(2):201-208

Çimrin T, Demirel M. The effects of dietary Rosemary (Rosmarinus officinalis L.) essential oil supplementation on laying hen performance, egg quality and oxidative stability of egg." Turkish Journal Of Agriculture Food Science And Technology 2016;4(2):113-119.

De Almeida GF, Horsted K, Thamsborg SM, Kyvsgaard NC, Ferreira JFS, Hermansen JE. Use of Artemisia Annua as a natural coccidiostat in freerange broilers and its effects on infection dynamics and performance. Veterinary Parasitology 2012;186(3-4):178-187.

Dho-Moulin M, Fairbrother JM. Avian pathogenic Escherichia Coli (APEC). Veterinary Research 1999;30(2-3):299-316.

Drăgan L, Györke A, Ferreira JFS, Pop IA, Dunca I, Drăgan M, et al. Effects of Artemisia annua and Foeniculum vulgare on chickens highly Infected with Eimeria tenella (Phylum Apicomplexa). Acta Veterinaria Scandinavica 2014;56(1):22

Erel O. A novel automated direct measurement method for total antioxidant capacity using a new generation, more stable ABTS radical cation. Clinical Biochemistry 2004;37(4):277-285.

Erel O. A new automated colorimetric method for measuring total oxidant status. Clinical Biochemistry 2005;38(12):1103-1111.

Ericsson M. Stress in chickens: effects of domestication and early experience on behaviour and welfare [doctoral dissertation]. Linköping (SE); Linköping University; 2016.

Fahey AG, Cheng HW. Group size and density effects on physical ındices and cell-mediated Immunity in two genetic lines of white leghorn layers. Poultry Science 2008;87(12):2500-2504.

Fellenberg MA, Speisky H. Antioxidants: their effects on broiler oxidative stress and its meat oxidative stability. World's Poultry Science Journal 2006;62(1):53-70.

Fidan DE. Breeding parameters, phenotypic correlations among parameters with the effects of cage position and stocking density on stress and performance in the laying period in Denizli chickens [doktoral dissertation]. Aydın (TR): Adnan Menderes University; 2010.

Galobart J, Barroeta AC, Baucells MD, Codony R, Ternes W. Effect of dietary supplementation with Rosemary extract and $\alpha$-tocopheryl acetate on lipid oxidation in eggs enriched with w3-fatty acids. Poultry Science $2001 ; 80(4): 460-467$

Gharetappe FK, Hassanabadi A, Semnaninezhad H, Nassiry MR. The effect of dietary tarragon (Artemisia dracunculus) and peppermint (Mentha piperita) leaves on growth performance and antibody response of broiler chickens. Iranian Journal of Applied Animal Science 2015;5(2):403409.
Gholamrezaie SL, Mohammadi M, Jalali SJ, Abolghasemi SA, Roostaie AM. Extract and leaf powder effect of artemisia annua on performance, cellular and humoral ımmunity in broilers. Iranian Journal of Veterinary Research 2013;14(1):15-20.

Gray HG, Paradis TJ, Chang PW. Physiological effects of adrenocorticotropic hormone and hydrocortisone in laying hens. Poultry Science 1989;68(12):1710-1713

Guesdon V, Ahmed AMH, Mallet S, Faure JM, Nys Y. Effects of beak trimming and cage design on laying hen performance and egg quality. British Poultry Science 2006;47(1):1-12.

Hosseinzadeh Z, Moghaddam G. Effects of tarragon powders' different levels (Artemisia dracunculus) on general performance and anetometric properties of digestive system of male broiler chickens. International Journal of Advanced Biological and Biomedical Research 2014;2(5):1599-1605.

Jahanian R, Ashnagar M. Effect of dietary supplementation of mannanoligosaccharides on performance, blood metabolites, ıleal nutrient digestibility, and gut microflora in escherichia coli-challenged laying hens. Poultry Science 2015;94(9):2165-2172.

Jalal MA, Scheideler SE, Marx D. Effect of bird cage space and dietary metabolizable energy level on production parameters in laying hens. Poultry Science 2006;85(2):306-311.

Karaalp M, Aksakal V, Sarikaya SBO, Urusan H, Bayram B, Zulkadir A. The effect of apple cider vinegar and mushroom stalk supplementation on laying hens. Indian Journal of Animal Research 2018;52(10):14571461.

Karabayır A, Uzun O, Çakır G. Effects of stocking density on some egg quality parameters in caged Japanese quails (Coturnix coturnix japonica)." Alinteri Journal of Agriculture Sciences 2010;19:1-6.

Kassaify ZG, Mine Y. Nonimmunized egg yolk powder can suppress the colonization of Salmonella typhimurium, Escherichia coli 0157:H7, and Campylobacter jejuni in laying hens. Poultry Science 2004;83(9):14971506

Kaya A, Turgut L. Effects of sage (Salvia Officinalis), thyme (Thymbra spicata), mentha (Menthae piperitae) extracts and vitamin e supplementation at different levels into diets of hens on performance, egg quality and yolk tbars value. Journal of Agricultural Faculty of Atatürk University 2012;43(1):49-58.

Kaya $\mathrm{H}$, Macıt M. The effects of boron (Orthoboric acid) supplementation into diets of laying hens on egg shell quality and tibia biomechanic parameters and serum, shell and tibia mineral concentrations during late laying period. Atatürk University Journal of Veterinary Science. 2018;13(1):42-53.

Khalaji S, Zaghari M, Hatami KH, Hedari-Dastjerdi S, Lotfi L, Nazarian H. Black cumin seeds, Artemisia leaves (Artemisia sieberi), and Camellia L. plant extract as phytogenic products in broiler diets and their effects on performance, blood constituents, Immunity, and cecal microbial population. Poultry Science 2011;90(11):2500-2510.

Kheirabadi KP, KatadJ JK, Bahadoran S, Silva JAT da, Samani AD, Bashi MC. Comparison of the anticoccidial effect of granulated extract of Artemisia sieberi with monensin in experimental coccidiosis in broiler chickens. Experimental Parasitology 2014;141:129-33.

Kordali S, Kotan R, Mavi A, Cakir A, Ala A, Yildirim A. Determination of the chemical composition and antioxidant activity of the essential oil of Artemisia dracunculus and of the antifungal and antibacterial activities of Turkish Artemisia absinthium, A. dracunculus, Artemisia santonicum, and Artemisia spicigera essential oils. Journal of Agricultural and Food Chemistry 2005;53(24):9452-9458. 
Kostadinovic L, Levic J, Galonja-Coghill T, Ruzicic L. Anticoccidian effects of the Artemisia absinthium L. extracts in broiler chickens. Archiva Zootechnica 2012;15(2):69-77.

Kostadinović L, Lević J, Popović S, Čabarkapa I, Đuragić O, Kormanjoš A, et al. Dietary inclusion of Artemisia absinthium for management of growth performance, antioxidative status and quality of chicken meat. European Poultry Science 2015;79:1-10.

Krause EL, Ternes W. Bioavailability of the antioxidative Rosmarinus officinalis compound carnosic acid in eggs. European Food Research and Technology 2000;210(3):161-164

Kutlu HR, Forbes JM. Changes in growth and blood parameters in heatstressed broiler chicks in response to dietary ascorbic acid. Livestock Production Science 1993; 36(4):335-350.

Li Z, Nestor KE, Saif YM, Anderson JW, Patterson RA. Serum ımmunoglobulin $\mathrm{g}$ and $\mathrm{m}$ concentrations did not appear to be associated with resistance to pasteurella multocida in a large-bodied turkey line and a randombred control population. Poultry Science 2000;79(2):163-166.

Li $X L$, He WL, Wang ZB, Xu TS. Effects of chinese herbal mixture on performance, egg quality and blood biochemical parameters of laying hens. Journal of Animal Physiology and Animal Nutrition 2016;100(6):1041-1049

Lopes-Lutz D, Alviano DS, Alviano CS, Kolodziejczyk PP. Screening of chemical composition, antimicrobial and antioxidant activities of Artemisia essential oils. Phytochemistry. 2008; 69(8):1732-1738.

Mirfendereski E, Jahanian R. Effects of dietary organic chromium and vitamin c supplementation on performance, Immune responses, blood metabolites, and stress status of laying hens subjected to high stocking density. Poultry Science 2015;94(2):281-88.

Moberg, GP, Mench JA. The biology of animal stress: basic principles and Implications for animal welfare. Wallingford: Cabi Publishing; 2000

Munck A, Guyre PM, Holbrook NJ. Physiological functions of glucocorticoids in stress and their relation to pharmacological actions. Endocrine Reviews 1984;5(1):25-44.

Murray DL, Brake J, Thaxton JP. Effect of adrenocorticotropin and dietary ascorbic acid on cutaneous basophil hypersensitivity to phytohemagglutinin in chickens. Poultry Science 1987;66(11):18461852.

Nahashon SN, Adefope NA, Amenyenu A, Wright D. Laying performance of pearl gray guinea fowl hens as affected by caging density. Poultry Science 2006;85(9):1682-1689.

Omidpanah S, Vazirian M, Hadjiakhondi A, Nabavi SM, Manayi A. Evaluation of antibacterial activity of some medicinal plants against Isolated escherichia coli from diseased laying hens. Progress in Nutrition 2016;18(4): 429-435.

Onbaşılar EE, Aksoy FT. Stress parameters and ımmune response of layers under different cage floor and density conditions. Livestock Production Science 2005:95(3):255-263.

Onbaşılar EE, Demirtaş ŞE, Kahraman Z, Karademir E, Demir S. The Influence of different beak trimming age on performance, $\mathrm{H}$-L ratio and antibody production to SRBC in laying hens. Tropical Animal Health and Production 2009;41(2):221-227.

Onbaşılar EE, Ünal N, Erdem E. Some egg quality traits of two laying hybrids kept in different cage systems. Ankara Üniversitesi Veteriner Fakültesi Dergisi 2018;61:51-55.

Pardue SL, Thaxton JP. Evidence for amelioration of steroid-mediated Immunosuppression by ascorbic acid. Poultry Science 1984;63(6):12621268.
Proietti PC, Castellini C, Pedrazzoli M, Dal Bosco A. Bacterial counts and characterization of intestinal flora in organic and conventional chickens. Proceedings of the 12th European Poultry Conference; 2006. Verona Italy: World's Poultry Science Association (WPSA); 2006.

Radwan N, Hassan LR, Qota EM, Fayek HM. Effect of natural antioxidant on oxidative stability of eggs and productive and reproductive performance of laying hens. International Journal of Poultry Science $2008 ; 7(2): 134-150$

Ralph CR, Tilbrook, AJ. Invited Review: The usefulness of measuring glucocorticoids for assessing animal welfare. Journal of Animal Science 2016;94(2):457-470

Ramírez-Tortosa MC, Mesa MD, Aguilera MC, Quiles JL, Baró L, RamirezTortosa CL, Martinez-Victoria E, GiL A. Oral administration of turmeric extract Inhibits Idl oxidation and has hypocholesterolemic effects in rabbits with experimental atherosclerosis. Atherosclerosis 1999;147(2):371-378.

Sahin K, Sahin N, Yaralioglu S. Effects of vitamin C and vitamin E on lipid peroxidation, blood serum metabolites, and mineral concentrations of laying hens reared at high ambient temperature. Biological Trace Element Research 2002;85(1):35-45.

Sahin K, Sahin N, Kucuk O. Effects of chromium, and ascorbic acid supplementation on growth, carcass traits, serum metabolites, and antioxidant status of broiler chickens reared at a high ambient temperature $\left(32^{\circ} \mathrm{C}\right)$. Nutrition Research. 2003;23(2):225-238.

Sahin, S, Macit M, Esenbuğa N, Karaca H. Effect of cage density on performance and egg quality traits of layers. Journal of Applied Animal Research 2007;31(1):37-39.

Sarica M, Boga S, Yamak US. The effects of space allowance on egg yield egg quality and plumage condition of laying hens in battery cages. Czech Journal of Animal Science 2008;53(8):346-353.

Simsek E, Kilic I. Building environment and Interaction of population density and position and their relationship to layer performance. International Journal of Poultry Science 2006;5(9):856-862.

Sohail SS, Bryant MM, Roland DA. Effect of reducing cage density on performance and economics of second-cycle (force rested) commercial Leghorns. Journal of Applied Poultry Research 2004;13(3):401-405.

Sohail MU, Rahman ZU, ljaz A, Yousaf MS, Ashraf K, Yaqub T, et al. Single or combined effects of mannan-oligosaccharides and probiotic supplements on the total oxidants, total antioxidants, enzymatic antioxidants, liver enzymes, and serum trace minerals in cyclic heatstressed broilers. Poultry Science 2011;90(11):2573-2577.

SPSS. SPSS advanced model. Version 11.5. Illinois; 2002.

Światkiewicz S, Koreleski J, Arczewska A. Laying performance and eggshell quality in laying hens fed diets supplemented with prebiotics and organic acids. Czech Journal of Animal Science 2010;55(7):294-304.

Taheri HR, Rahmani HR, Pourreza, J. Humoral Immunity of broilers is affected by oil extracted propolis (OEP) in the diet. International Journal of Poultry Science 2005; 4(7):414-417.

TSE - Turkish Standards Institute. Animal feeds-determination of metabolizable energy (chemical method) [Publ. 9610]. Ankara (TUR); 1991.

Von Eugen K, Nordquist RE, Zeinstra E, Van Der Staay, FJ. Stocking density affects stress and anxious behavior in the laying hen chick during rearing. Animals 2019;9(2):53.

Wenk C. Why all discussion about herbs? Biotechnology in the feed industry. Proceeding of Alltechs 16th Annual Symposium Alltech Technical Publications; 200. Nicholasvile (KY): Nottginham University Press; 2000 
Windisch W, Schedle K, Plitzner C, Kroismayr A. Use of phytogenic products as feed additives for swine and poultry. Journal of Animal Science 2008;86(14):E140-48.

Witkowska D, Sowińska J. The effectiveness of peppermint and thyme essential oil mist in reducing bacterial contamination in broiler houses. Poultry Science 2013;92(11):2834-2843.

Yilmaz O, Kaban G, Kaya M. Essential oil compounds of tarragon and coriander seed. Bayburt University Journal Science 2019;2(1):17-24 